\title{
Evaluation of Upliftment of Scheduled Tribes under MGNREGA
}

\author{
Keshlata \\ Research Scholar, Deptt.Of Sociology School of Humanities \& Social Sciences Gautam Buddha University, \\ Greater Noida
}

\begin{abstract}
According to new World Bank's estimation (2005 data) India has 456 million people about 41.6 percent which is below the new International poverty line of $\$ 1.25$ (ppp) per day. According to census, 2011 Indian population was 1.21 billion which has been enhance to about 1,270,272,105 (1.27 billion) till March, 2014 and it is the country where majority of people resides in the rural sector. In order to increase the growth of agriculture, the Government has planned several programs (SGSY, RLEGP and MGNREGA etc.) pertaining to rural development in India. The MGNREGA (Mahatma Gandhi National Rural Employment Guarantee Act) provides guarantee employment to the rural households and ensures the livelihood security of the poor by creating durable assets. Through this research paper an attempt has been done to evaluate the development of Scheduled tribes through MGNREGA.
\end{abstract}

Key Words: MGNREGA, HDI, PRIs, Social Audit, GP, Socio-economic Empowerment, Scheduled Tribes and Vulnerable Group

\section{Introduction}

The largest number of poor resides in South Asia where the largest percentage of its share is in India. According to new World Bank's estimation (2005 data) India has 456 million people about 41.6 percent which is below the new International poverty line of $\$ 1.25$ (ppp) per day. The estimation is also that 33 percent of the global poor now reside in India. .i. ccording to census, 2011 Indian population was 1.21 billion which has been enhance to about $1,270,272,105^{\mathrm{iii}}$ (1.27 billion) till March, 2014 and it is the country where majority of people resides in the rural sector. India is depends on agriculture. The development of infrastructure of a country is depends upon its economic growth. According to Indian Human Development Report, 2011 estimates the HDI of last some years Delhi, Kerala shows high Human Development Index.

Table1: Human Development Index pertaining to Rank of States during years 1999-00 to 2011-12

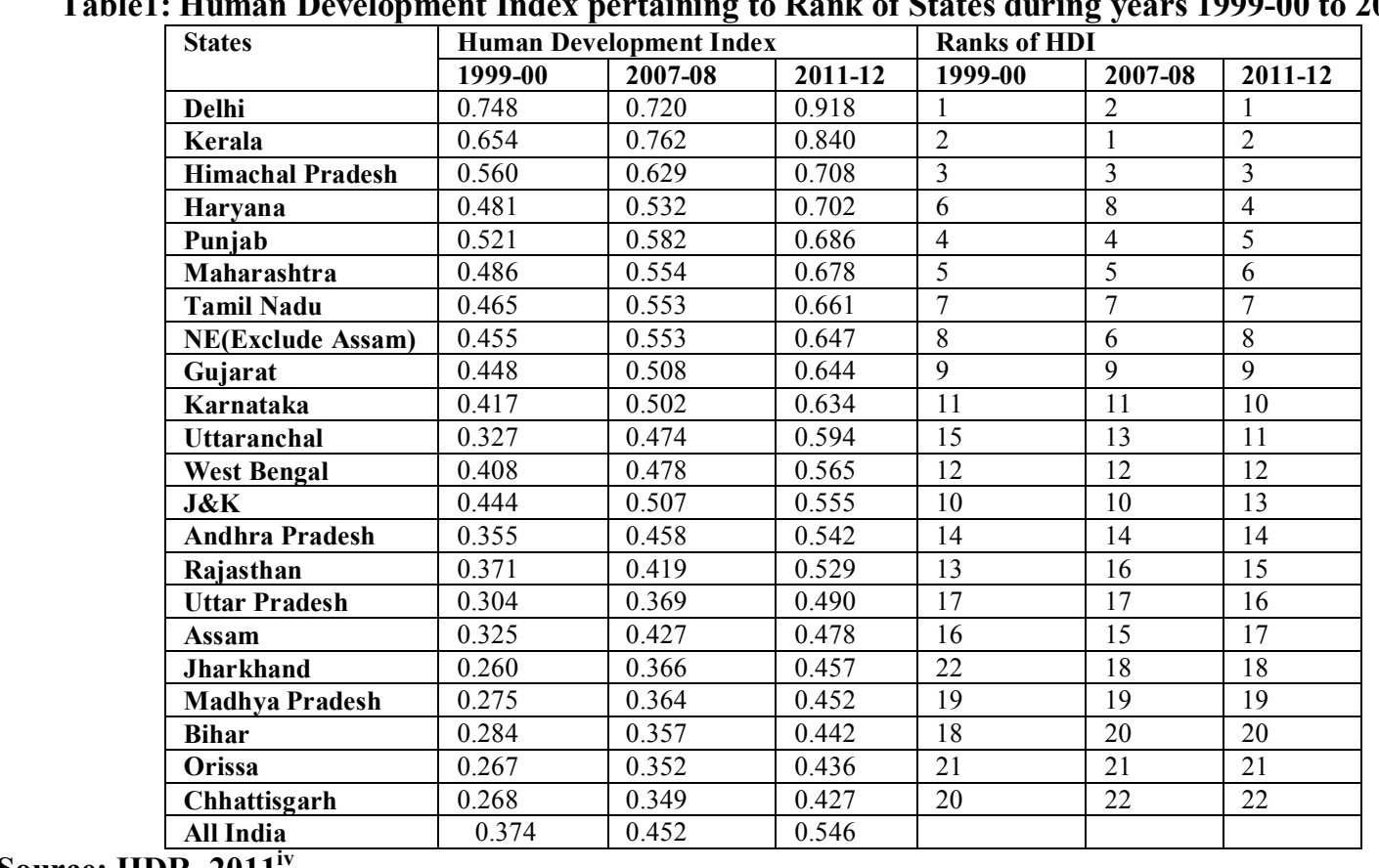

Source: HDR, 2011

According to above table the Indian Human Development Report, 2011 estimates the HDI from 201112, the Delhi and Kerala shows high Human Development Index. The states Himachal Pradesh, Haryana, 
Punjab, Maharashtra, Tamil Nadu Karnataka, Gujarat, West Bengal, Uttaranchal, North East India (Excluding Assam) and Jammu \& Kashmir shows medium Human Development Index and the states Andhra Pradesh, Rajasthan, Uttar Pradesh, Assam, Jharkhand, Madhya Pradesh, Bihar, Orissa and Chhattisgarh shows low Human Development Index.

Here, in India which follows a typical caste system there are Scheduled Castes (SCs) compromises about 16.6 percent and Scheduled Tribes (STs) compromises about 8.6 percent $^{v}$ of India's total population and are two groups of historically disadvantages people recognized in the constitution of India. Since 1850 the Scheduled Tribes communities are referred to as depressed classes or Adivasis (original inhabitants) ${ }^{\text {vi }}$. Poverty is the major problem in the development of India because poverty effects health, education, living standard, household dignity of life, shelter etc. of the peoples under below poverty line. Earlier so many planning were implemented by the Government of India to overcome from poverty such as IRDP, EAS, etc. Keeping special focus on forest villages and PTGs, special strategies have adopted during tenth plan with preventive-cumcurative-cum-remedial measures with improve extension of health, knowledge, infrastructure, immunization services. In India the Scheduled Tribes are still today illiterate, poor, resource-less, malnutritive, deprived, and exploited. Their condition in society still remains pitiable. Through this research paper we will try to focus the major hindrances in the development of Scheduled Tribes and role of MGNREGA in the upliftment of Scheduled Tribes.

\section{Concept of MGNREGA}

In India for rural development various strategies and programs through Government are have been implemented for rural development such as Integrated Rural Development Programs, Wage Employment Programs, Employment Assurance Scheme, Food for Work Programs, Rural Housing, Social Security Programs and Land Reforms etc. and even are still forwarded, in which MGNREGA has precious contribution. NREGA Act was passed in 2005 that guaranteed 100 days wage of employment in a year to every rural household. Government of India has renamed the NREGA as MGNREGA on $2^{\text {nd }}$ October 2009. On 2, Feb, 2006 it was launched in 200 select districts and was extended to 130 additional districts during 2007-08 ${ }^{\text {vii }}$. It is now implemented in 645 districts of the country. ${ }^{\text {viii }}$ Under MGNREGA work is provided for about 90 days for every households reside in villages. In this case, rural people have to gone through a process for getting employment. First of all, every rural household supposed to get registered them to local Gram Panchayat for seeking employment, then within 15 days job cards containing photographs are issued to all entitled applicants. After getting job cards, work is allotted to job card holders within 15 days. In case, failed to provided work wage is given as per day schedule.

The nature of MGNREGA work is unskilled manual work and this is targeted to enhance livelihood security of every rural people by providing Guaranteed Wage Employment for 90 days and in that process of employment generation durable assets are build up as it focus the work of water and soil conservation, afforestation and land development, irrigation, rural connectivity, flood protection, drought proofing etc. the projects for villages are recommended by gram sabha approved by Jila Panchayat, whereas 50 percent works ${ }^{\text {ix }}$ should be implemented by gram panchayat. The Panchayati Raj Institutions (PRIS) plays principal role over planning and implementation.

According to C.P. Chandrasekhar and JayatiGhosh, "The NREGA is necessarily 'inclusive' at the most basic level in the economic terms, because is self-targets those who are willing to engage in arduous physical work for a daily wage, in other words the poorest sections of society. But it is also socially inclusive as well, that, it disproportionately involves women, SCs and STs as workers in the scheme." ${ }^{*}$

According to many analysts, "the programmme is boosting the purchasing power of the rural poor and has led to a stable income for the rural population. The most eligible rural families that the NREGA hope to benefit are those of the landless-lobours as well as the small and marginal farmers." ${ }^{\text {xi }}$

\section{Concept of Scheduled Tribes}

Scheduled Tribes is a group of people who are socially and economically backward and isolated.There is so much confusion regarding the aboriginality of Indian Scheduled Tribes. According to a view tribal are preAryan inhabitants of India e.g. The descendants of the Dasyus are Santhal, Munda, Gondsetc tribes. On the other hand according to historians the Negritoes were the natives of India but unfortunately they disappeared and were followed by Austro-Asiatics. Another view prevails that the Pre-Dravidians were original inhabitants and followed by Mongoloids as Naga, Bodos etc. Futher as we know that Guha's classification of the Scheduled Tribes was categorized into three major classes as Negritoes, Proto-Austroloids and Monogoloids. In the period between $800-600 \mathrm{BC}$ due to continues migration of the tribes it is very difficult to pin-point their exact place of origin eg. The most populous tribe of central and western India the Bhils have migrated from north-west into Malwa. ${ }^{\text {xii }}$ 
According to the Ministry of Tribal Affairs, Government of India, "The term Scheduled Tribes first appeared in the constitution of India. Article 366 (25) defined Scheduled Tribes as such tribes or tribal communities or parts of or groups within such tribes or tribal communities as are deemed under article 342 to be Scheduled Tribes for the purposes of this constitution"

According to the Oxford Dictionary, "In India a tribal is listed in the Eight Schedule of the Indian constitution and recommended for special help in education and employment."

\section{Objectives}

Through this research paper, we have evaluated the effectiveness of MGNREGA in the concern of Scheduled Tribes. The research paper has following broad objectives.

1. To study the major factors which are responsible for poverty and backwardness of Scheduled Tribes?

2. To evaluate the impact of MGNREGA on the socio-economic empowerment of Scheduled Tribes.

\section{Methodology}

We have adopted the qualitative research where primary data sources as planning Commission, Ministry of Rural Development Annual reports, census etc. and secondary data sources as Books, Articles, Research Papers are used to complete this research paper.

\section{Socio-economic Empowerment of Scheduled Tribes under MGNREGA}

(a) Financial Structure of MGNREGA

Table 2: Social Audit Reportduring Financial Years 2011-12 to 2013-14

\begin{tabular}{|l|l|l|l|l|l|l|}
\hline $\begin{array}{l}\text { Financial } \\
\text { Year }\end{array}$ & $\begin{array}{l}\text { Total Districts } \\
\text { Covered }\end{array}$ & $\begin{array}{l}\text { No. of Districts } \\
\text { Started Social } \\
\text { Audit }\end{array}$ & Total GP & $\begin{array}{l}\text { No. } \\
\text { panchayat } \\
\text { Covered }\end{array}$ & $\begin{array}{l}\text { No. of Social } \\
\text { Audit }\end{array}$ & $\begin{array}{l}\text { Issue Raised \& } \\
\text { Action Taken }\end{array}$ \\
\hline $2011-12$ & 645 & 527 & 247834 & 176235 & 291483 & 132160 \\
\hline $2012-13$ & 645 & 555 & 297853 & 175494 & 327546 & 152735 \\
\hline $2013-14$ & 645 & 508 & 247834 & 118620 & 186964 & 117217 \\
\hline
\end{tabular}

Source: www.nrega.nic.in

Above table reveals that according to the Social Audit Report number of districts started Social Audit, total Gram Panchayats, Number of Social Audit and issue raised and action taken were increased during financial Year 2012-13 from 2011-12 and decreased during Financial Year 2013-14 from 2012-13. It shows a up and down graph. But abobe these all are least during Financial Year 2013-14.

\section{(b) Empowerment of Vulnerable Group (SCs, STs and Women)}

MGNREGA is a demand driven scheme where 100 days of employment is generated to any rural household whose adult members are willing to do unskilled manual work. Hence separate earmarking of employment for SCs/STs has not been provided, although the reports of physical achievements during Financial Year 2006-07 to Financial Year 2012-13 is as follows:

Table 3: Employment generated to Vulnerable Group (SCs, STs and Women) During Financial Years 2006-07 to 2012-13

\begin{tabular}{|c|c|c|c|c|c|}
\hline S.N. & Financial Years & $\begin{array}{l}\text { Total person days } \\
\text { (in Crores) }\end{array}$ & $\begin{array}{l}\text { Employment } \\
\text { generated to SCs (in } \\
\text { Crores) }\end{array}$ & $\begin{array}{l}\text { Employment } \\
\text { generated to STs (in } \\
\text { Crores) }\end{array}$ & $\begin{array}{l}\text { Employment } \\
\text { generated to Women } \\
\text { (in Crores) }\end{array}$ \\
\hline $1^{\text {xiii }}$ & $2006-07$ & 62.01 & 15.58 (25.13 Percent) & 23.46 (37.03 Percent) & 24.26 (39.13 Percent) \\
\hline $2^{\mathrm{xiv}}$ & $2007-08$ & 96.03 & 25.90 (26.97 Percent) & 29.40 (30.62 Percent) & 41.52 (43.23 Percent) \\
\hline $3^{\mathrm{XV}}$ & $2008-09$ & 216.01 & 63.39 (29 Percent) & 54.78 (25 Percent) & 103.41 (48 Percent) \\
\hline $4^{\mathrm{xvi}}$ & $2009-10$ & 191.16 & 57.41 (30 Percent) & 41.48 (22 Percent) & 95.56 ( 50 Percent $)$ \\
\hline $5^{\mathrm{xvii}}$ & $2010-11$ & 145 & 32.65 (23 Percent) & 24.83 (17 Percent) & 72.93 (50 Percent) \\
\hline $6^{\text {xviii }}$ & $2011-12$ & 120.88 & 27.40 (23 Percent) & 20.69 (17 Percent) & 59.82 (49 Percent) \\
\hline $7^{\mathrm{xix}}$ & $2012-13$ & 134.76 & 30.28 (22.47 Percent) & 20.80 (15.43 Percent) & 71.88 (53 Percent) \\
\hline
\end{tabular}

Source: Annual Reports 2006-07 to 2012-13, Ministry of Rural Development, Government of India

Above table reveals that the employment generated for the vulnerable group (SCs, STs and women) under MGNREGA is good. Employment generated for STs with compare to SCs was high during financial Years 2006-07 to 2007-08, but low during Financial Years 2008-09 to 2012-13. On the other hand, work generated for women was quite high from the beginning with compare to SCs and STs respectively. 
(c) Empowerment of Scheduled Tribes (STs)

The name of states where MGNREGA has been implemented are: Andhra Pradesh, Arunachal Pradesh, Assam, Bihar, Chhattisgarh, Goa, Gujarat, Haryana, Himachal Pradesh, Jammu and Kashmir, Jharkhand, Karnataka, Kerala, Madhya Pradesh, Maharashtra, Manipur, Meghalaya, Mizoram, Nagaland, Odisha, Punjab, Rajasthan, Sikkim, Tamil Nadu, Tripura, U.P., Uttarakhand, West Bengal, Andaman and Nikobar, Chandigarh, Dadra and Nagar Haveli, Daman \& Diu, Lakshadweep and Pondicherry.

As we know that Madhya Pradesh has large numbers of scheduled tribes. Out of total scheduled tribe's population of 67.76 million, about $49 \%$ of the scheduled tribe's population in three states viz., Madhya Pradesh $(27.73 \%)$, Maharashtra $(10.80 \%)$ and Orissa $(10.38 \%)$. About $93 \%$ of the scheduled tribe population is rural based.The scheduled tribe's population of the state of Madhya Pradesh is 12,233,474 as per 2001 census. $^{\mathrm{xx}}$ Although several anti-poverty programmes and policies have been implemented in the tribal areas for improvement of socio-economic condition of the tribal. In terms of broader development parameters i.e. literacy, health indicators and below poverty line they are in the last ladder of the development. We have a provision of poverty eradication since 1951 till 2013 (near about 65 years plus). Poverty is one of the factors and affects the life of people in general and tribal in particular.

In Madhya Pradesh Actual person Days generated up to February, 2014 in lakh (as per MIS) were 871.97 and in Uttar Pradesh was 1553.27. On the other hand the expenditure (February, 2014) as per MIS (in Lakhs) was 192708.48 in Madhya Pradesh and in Uttar Pradesh it was 312234.46. ${ }^{\text {xxi }}$

Table 4: In Madhya Pradesh the Cumulative Number of Households Issued Job Cards and Cumulative Number of Person daysgenerated to SCs and STs from Financial Year 2014 till the Reporting Report

\begin{tabular}{|l|l|l|}
\hline Category & $\begin{array}{l}\text { Cumulative No. of Households Issued Job } \\
\text { cards }\end{array}$ & Cumulative Person days Generated \\
\hline Scheduled Castes & 657233 & 1665682 \\
\hline Scheduled Tribes & 1362698 & 4146384 \\
\hline Total & 4414137 & 11219024 \\
\hline
\end{tabular}

Source: www.nrega.nic.in

According to above table we can say that the Cumulative No. of Households Issued Job cards and Cumulative Person days generated During Financial Year 2014 to Scheduled Tribes in Madhya Pradesh is higher than Scheduled Castes.

Factors Responsible for the Backwardness of Scheduled Tribes

Some factors which are responsible for the backwardness of Scheduled Tribes are as follows:

\section{Personal Factors}

(1) Migration: Scheduled Tribes livelihood basically depends on the agriculture and collection of minor forest produce (as gum from Cheed named tree etc.). For the purpose of several tribal development integrated projects they have been deprived from forests and lands. So for their survival they usually migrate to city and other states for working as wage laborers, bonded labour at brick kilns.

(2) Poor availability of Education: Children are hardly sent to the schools. As per their needs there is poor availability of education facilities for the children due to which child faces extremely difficulty to cope with the school curriculum because of non-availability of teachers and study materials, long distance, ill timing of schools, negative attitude of both parents and teachers and low or negligible female literacy rates and so on.

(3) Poor health facilities: At the time of serious illness or emergency of the Scheduled Tribes they have to depend on bi-cycle or walk to nearby Government hospitals where there is no provision to look after them seriously.

(4) Lack of awareness and consciousness: Through state and central governments several schemes and programmes have been implemented for poverty alleviation of STs, but could not change the conditions of the poor because of their unawareness and consciousness about the various development schemes and programmes. ${ }^{\text {xii }}$

Factors/hindrances under MGNREGA Implementation

(5) Dated receipt not given to applicants,

(6) work not provided within 15 days,

(7) Unemployment allowance not paid.

(8) Poor participation of Gram Sabhas (GSs): At the time of planning of works the main issues found were not enough participation of Gram Sabhas (GSs) as poor planning, shortage of technical staff with Gram Panchayats for planning etc. 
(9) Non-availability of worksite facilities: During the work site management the main issues were not availability of worksite facilities as job cards were not updated, measurement not done on time, presence of machinery or contactors etc.

(10) Delays in payment: At the time of wage and wage payment the issues were related to delays in payment which cross 2-3 months, banks and post offices do not have its branches or staff.

(11) Lacking of transparency and social audit: social audit not conducted, non-availability of active vigilance committees, no records made available of the events in the case of social audit done etc. ${ }^{\text {xiii }}$

\section{Conclusion}

On the basis of above discussion it is concluded that the Scheduled Tribes are in the last ladder of development in terms of broader development parameters i.e. literacy, health indicators and below poverty line. We have a provision of poverty eradication since 1951 till 2013 (near about 65 years plus). Poverty is one of the factors which affects the life of people in general and tribal in particular. For providing better livelihood opportunities and durable assets NREGA Act was passed in 2005 that guaranteed 100 days wage of employment in a year to every rural household. Government of India has renamed the NREGA as MGNREGA on $2^{\text {nd }}$ October 2009. On 2, Feb, 2006 it was launched in 200 select districts and was extended to 130 additional districts during 2007-08 ${ }^{\text {xxiv }}$. It is now implemented in 645 districts of the country. ${ }^{\mathrm{xxv}}$ Under MGNREGA work is provided for about 100 days for every households reside in villages. It cannot be denied that tribal households have been benefited from MGNREGA and empowered them socially and economically to some extent, although they need special focus and attention. The awareness is lacking in STs as they are mostly illiterate and still today stuck with their old traditions and habits as drinking alcohol, early marriage and so on. They actually required proper participation in Gram Sabhas, field survey should be held about their genuine problems, assembly should be organize for their awareness. They are indeed isolated, so they need to connect with us in every way. Along with this MGNREGA work implementation should be done honestly to give them better livelihood and it should not be limited to on paper record based.

Other than MGNREGA several schemes and programmes have been implemented through state and central governments for providing better livelihood to STs, but insufficient awareness and lack of organized efforts seems to be the root causes of socio-economic backwardness and major problems of the Scheduled tribes.

\section{References}

[1]. Census, 2011, New Delhi.

[2]. Arunachalam, P., Mahatma Gandhi National Rural Employment Guarantee Programme and Poverty in India, New Delhi: Serial Publication, 2011, pp. 6

[3]. Census, 2011, New Delhi.

[4]. Indian Human Development Report, 2011, Planning Commission

[5]. ibid

[6]. Ministry of Social Justice and Empowerment, New Delhi,

[7]. Annual Report 2006-07, Ministry of Rural Development, Government of India, p. 2

[8]. www.nrega.nic.in

[9]. Annual Report 2006-07, Ministry of Rural Development, Government of India, p. 2

[10]. Arunachalam, P., Mahatma Gandhi National Rural Employment Guarantee Programme and Poverty in India, New Delhi: Serial Publication, 2011, pp. 58

[11]. Ibid, p.58

[12]. Shrivastav, Divya, The Development of Scheduled Tribes in Madhya Pradesh, New Delhi, Gyan Publisher, 2000, pp. 21-22

[13]. Annual Report 2006-07, Ministry of Rural Development, Government of India, pp. 2-3

[14]. Annual Report 2007-08, Ministry of Rural Development, Government of India, p.6

[15]. Annual Report 2008-09, Ministry of Rural Development, Government of India, p. 72, p.74

[16]. Annual Report 2009-10, Ministry of Rural Development, Government of India, p.65, p.67

[17]. Annual Report 2010-11, Ministry of Rural Development, Government of India, p.ix

[18]. Annual Report 2011-12, Ministry of Rural Development, Government of India, pp.82-83, p.85

[19]. Annual Report 2012-13, Ministry of Rural Development, Government of India, p.92, p.93, p.xiv

[20]. DivyaShrivastava, The Development of Scheduled Tribes in Madhya Pradesh, New Delhi: Gyan Publisher, 2000, Page No.-7

[21]. www.nrega.nic.in

[22]. www.ycdaindia.org

[23]. MGNREGA Sameeksha, Ministry of Rural Development, Government of India, (2006-12), p.70

[24]. Annual Report 2006-07, Ministry of Rural Development, Government of India, p. 2

[25]. www.nrega.nic.in 